\title{
Titanium Dioxide Soaking Time Effects on DSSC Powers and Efficiency
}

\author{
Rika Musiana $^{1, *}$ Abu Hasan² RD Kusumanto ${ }^{2}$ \\ ${ }^{1}$ Applied Renewable Energy Engineering Study Program, Politeknik Negeri Sriwijaya, \\ Jalan Srijaya Negara, Palembang, 30139 Indonesia. \\ ${ }^{2}$ Renewable Energy Engineering Department, Politeknik Negeri Sriwijaya, Jalan \\ Srijaya Negara, Palembang, 30139 Indonesia. \\ *Corresponding author.Email: rika_agust@yahoo.com
}

\begin{abstract}
The purpose of this study was to study the power and efficiency of Dye Sensitized Solar Cell (DSSC) using extracts of yellow sweet potato (Ipomoea batatas L.) with variations in the soaking time of Titanium Dioxide paste (TiO2) in dye and light intensity. This research used descriptive method with several stages of research with a variation of DSSC treatment as many as 18 samples. Dye Sensitized Solar Cell (DSSC) is made using a Capacitive Touch Screen glass substrate. With a substrate size of $25 \mathrm{~mm} \times 25 \mathrm{~mm} \times 1,113 \mathrm{~mm}$. Dye Sensitized Solar Cell (DSSC) was tested with 6 (six) variations of the soaking time of $\mathrm{TiO} 2$ in the sensitizer, namely: 0 seconds, 5 seconds, 10 seconds, 15 seconds, 20 seconds, and 25 seconds. The parameters observed were DSSC power and efficiency. DSSC 9 is DSSC which has the highest overall output power value that is valued at $0.012 \mathrm{~mW}$ and the lowest is obtained from DSSC 11 and 17 which is equal to $0,00056 \mathrm{~mW}$. The value of DSSC efficiency at a distance of $10 \mathrm{~cm}$ from a light source is in the range of $0,00039 \%$ to $0.00235 \%$, at a distance of $20 \mathrm{~cm}$ DSSC has an efficiency ranging from $0,00038 \%$ to $0.00818 \%$, at a distance of $30 \mathrm{~cm}$ the DSSC efficiency is around between $0,00039 \%$ to $0.00304 \%$. The highest efficiency value was obtained from DSSC with a soaking time of 10 seconds.
\end{abstract}

Keywords: DSSC, yellow sweet potato, power, efficiency

\section{INTRODUCTION}

One of the big problems faced by humans is the continued depletion of energy, in which energy has a role and a major influence on the survival of humans throughout the world. According to the study Energy Outlook, especially in Indonesia, energy demand has increased, the need for primary energy has increased by $5 \%$, causing the effects of $\mathrm{CO}_{2}$ emissions which continue to increase and are harmful to the atmosphere. The high price of world oil makes fossil energy subsidies jump more than USD 400 million, it is also accompanied by consumer behavior in using energy inefficiently [10].

The sustainability of energy supply in the future depends on the paradigm of switching from non-fossil fuels that produce pollution to renewable sources [6]. There are so many energy needs that to meet those needs alternative energy is needed, namely renewable energy [4]. Solar energy can be converted into electrical energy so that the energy produced can be an alternative energy that minimizes and replaces the use of fossil fuels. Several renewable energy sources that can be used to overcome the energy crisis are solar, biomass, wind, and water. One alternative energy source that continues to be developed in meeting the need for electricity is solar energy [7]. In addition to its abundant availability of solar energy it is possible to use it as an energy generator in remote areas. Solar cells that have been widely developed and have high efficiency are first generation solar cells, namely conventional siliconbased solar cells. One of the solar cells that continues to be developed is a third generation solar cell, which is abased solar cell Titania or Dye Sensitized Solar Cell (DSSC) [8].

Michael Gratzel was a researcher who first discovered the Dye Sensitized Solar Cell (DSSC) with an efficiency reaching $11 \%$ in 1991 and patented the name Gratzel Cell. Gratzel explains that the principle of solar cells uses simple electrochemical principles that mimic the 
effects of photosynthesis by capturing photon energy and converting it into electrical energy [11].

Yellow sweet potato (Ipomoea batatas L.) is one of the tubers that originated from the American continent and has spread almost all over the world. The energy source in yellow sweet potato is carbohydrate and sugar. The yellow color of the leaves and stems of yellow sweet potato is caused by the presence of anthocyanin compounds. The anthocyanin pigment in yellow sweet potato has a higher concentration and is more stable when compared to anthocyanin from other sources. Data from previous studies conducted by [3] as for the levels of anthocyanin held by yellow sweet potatoes amounted to $31.16 \mathrm{mg}$ per $100 \mathrm{~g}$ of tubers, so that the anthocyanin pigment from yellow sweet potatoes is good to be used as a natural dye source for Dye Sensitized Solar Cell (DSSC).

The use of yellow sweet potato extract as an sensitizer organic in DSSC needs to be widely developed, one of which is in the province of South Sumatra which has the potential where yellow sweet potato can be easily cultivated. So that the energy conversion process with raw materials that are easily available, inexpensive, and environmentally friendly such as yellow sweet potato can take place in a sustainable manner, then it needs to be studied further including increasing efficiency so that the development of DSSC-based energy with organic sensitizers can compete with dyes inorganic. soaking of $\mathrm{TiO}_{2}$ paste into the dye with the aim that a lot of dye sticks to the surface of the Titanium Dioxide paste so that the conversion of solar energy into electrical energy is greater. The performance of a solar cell is influenced by the amount of electric current generated, the performance can be determined from various things such as the efficiency and value of the fill factor, while the value of the efficiency generated and the fill factor can be influenced by external factors and from within the solar cell construction itself.

Based on the background that has been described, further research is needed related to the variation of the soaking time of $\mathrm{TiO}_{2}$ paste into dye yellow sweet potato in the manufacture of Dye Sensitized Solar Cell (DSSC) to obtain the highest efficiency that allows optimal sunlight absorption. This study aims to study the power and efficiency of Dye Sensitized Solar Cell (DSSC) using yellow sweet potato extract (Ipomoea batatas L.) with variations in the soaking time of Titanium Dioxide paste $\left(\mathrm{TiO}_{2}\right)$ in dye and light intensity.

\section{RESEARCH METHOD}

The materials used in this study are Acetic Acid, Aquades, Iodide $0.5 \mathrm{~N}$, Carbon Catalyst (soot wax), Glass Transparent Conductive Oxide (TCO), to taste, Methanol, Titanium Dioxide $\left(\mathrm{TiO}_{2}\right)$ (Merck) and Sweet Potatoes yellow sweet potato.
The research method used is descriptive method with several stages of research including:

1. Preparation of structures Dye Sensitized Solar Cell (DSSC).

2. preparation and Dye Sensitized Solar Cell (DSSC) assembly.

3. testing Dye Sensitized Solar Cell (DSSC).

The Dye Sensitized Solar Cell (DSSC) is made using a glass substrate Capacitive Touch Screen. With a substrate size of $25 \mathrm{~mm} \times 25 \mathrm{~mm} \times 1,113 \mathrm{~mm}$. Dye Sensitized Solar Cell (DSSC) was tested with 6 (six) variations of the soaking time of $\mathrm{TiO}_{2}$ in the sensitizer, namely: 0 seconds, 5 seconds, 10 seconds, 15 seconds, 20 seconds, and 25 seconds, with a thickness of 4 layers of masking tape, where thickness of one layer of masking tape is $0.1235 \mathrm{~mm}$, according to the best thickness according to [1] research:

DSSC 1: Soaking for 0 seconds, light intensity $400.14 \mathrm{~m}$ $/ \mathrm{W}^{2}$

DSSC 2: soaking for 5 seconds, light intensity $400.14 \mathrm{~m}$ $/ \mathrm{W}^{2}$

DSSC 3: soaking for 10 seconds, light intensity 400.14 $\mathrm{m} / \mathrm{W}^{2}$

DSSC 4: soaking for 15 seconds, light intensity 400.14 $\mathrm{m} / \mathrm{W}^{2}$

DSSC 5: soaking for 20 seconds, light intensity 400.14 $\mathrm{m} / \mathrm{W}^{2}$

DSSC 6: soaking for 25 seconds, light intensity 400.14 $\mathrm{m} / \mathrm{W}^{2}$

DSSC 7: soaking for 0 seconds, light intensity $303.23 \mathrm{~m}$ $/ \mathrm{W}^{2}$

DSSC 8: soaking for 5 seconds, light intensity $303.23 \mathrm{~m}$ $/ \mathrm{W}^{2}$

DSSC 9: soaking for 10 seconds, light intensity 303.23 $\mathrm{m} / \mathrm{W}^{2}$

DSSC 10: soaking for 15 seconds, light intensity 303.23 $\mathrm{m} / \mathrm{W}^{2}$

DSSC 11: soaking for 20 seconds, light intensity 303.23 $\mathrm{m} / \mathrm{W}^{2}$

DSSC 12: soaking for 25 seconds, light intensity 303.23 $\mathrm{m} / \mathrm{W}^{2}$

DSSC 13: soaking for 0 seconds, light intensity 299.62 $\mathrm{m} / \mathrm{W}^{2}$

DSSC 14: soaking for 5 seconds, light intensity 299.62 $\mathrm{m} / \mathrm{W}^{2}$

DSSC 15: soaking for 10 seconds, light intensity 299.62 $\mathrm{m} / \mathrm{W}^{2}$

DSSC 16: soaking for 15 seconds, light intensity 299.62 $\mathrm{m} / \mathrm{W}^{2}$

DSSC 17: soaking for 20 seconds, light intensity 299.62 $\mathrm{m} / \mathrm{W}^{2}$

DSSC 18: soaking for 25 seconds, light intensity 299.62 $\mathrm{m} / \mathrm{W}^{2}$ 
Methods carried out in this study include:

1) Preparation of DSSC Structures Preparation of structures Dye Sensitized Solar Cell (DSSC) starts from cutting glass substrate, making sensitizer, making $\mathrm{TiO}_{2}$ paste and making comparative electrodes.

2) Glass Cutting Substrate

a) Glass substrate is Capacitive Touch Screen separated from the scratch-resistant coating and protective plastic.

b) Glass is marked using a pen to determine the desired area.

c) After the area is formed, the glass is cut using a glass cutter in an upright position.

d) The glass is washed thoroughly using distilled water and then dried using a tissue.

3) Making Sensitizer [3]

a) 40 grams of yellow sweet potato are cleaned using water, dried, aerated and cut into small pieces using a knife.

b) Sweet potatoes that have been weighed, then crushed or mashed on the mortar using a pestle.

c) Sweet potatoes that have been mashed, put into a glass beaker and soak with a solution of methanol: acetic acid: aquades (30: 4: 16 volume ratio).

d) The mixture of ingredients is stirred evenly using a stirring rod.

e) Leave the ingredients dissolved in methanol, acetic acid, and distilled water for 24 hours and store in a dark place.

f) The extract from the yellow sweet potato dye is filtered, using filter paper.

g) The results of the filtrate are stored in glass bottles coated with aluminum foil and placed in the refrigerator so that pigment degradation does not occur.

4) The making of $\mathrm{TiOPaste}_{2}$

a) Titanium Dioxide Powder $\left(\mathrm{TiO}_{2}\right)$ was weighed as much as $0.5 \mathrm{~g}$ and poured into a glass beaker $100 \mathrm{ml}$.

b) Then add $1 \mathrm{ml}$ of acetic acid and stir until the TiOpaste $_{2}$ is evenly mixed using a stirring rod.

5) Work Electrodes and Comparative Electrodes

a) The two conductive glass substrates, the working electrodes and the comparison electrodes are washed using methanol and rinsed with distilled water.

b) Use a multimeter to check the conductive sides of the two glass substrates. c) The tape is attached to the conductive side of the working electrode as a barrier with the provisions of the underside of $0.3 \mathrm{~cm}$ and $0.15 \mathrm{~cm}$ on the left and right sides.

d) The previously prepared Titanium Dioxide paste is deposited on a conductive glass and flattened using a glass spatula, then dried for 5 minutes using a dryer.

e) After the paste is dry, the glass substrate is put into the oven at $105^{\circ} \mathrm{C}$ for 5 minutes.

f) After being heated in the oven, the glass substrate is cooled to room temperature.

g) After being cooled, the glass substrate was extract dye dropped with $0.05 \mathrm{ml}$ of and then put into the oven again at $105^{\circ} \mathrm{C}$ for 5 minutes.

h) As for the comparison electrode glass, the conductive side of the glass is directed to the soot of fire from the wax until a clear layer of carbon is formed with the characteristic black glass.

i) Extent of carbon attached is removed using a cotton bud with a size of $0.15 \mathrm{~cm}$ right and left.

j) The bottom carbon side of the comparison electrode was also removed by an area of 0.3 $\mathrm{cm}$ to form an active surface area of $2.2 \mathrm{~cm} \mathrm{x}$ $2.2 \mathrm{~cm}$.

6) Preparation of DSSC Components

a) Glass working electrodes and comparative electrodes are stacked together in a position facing each other according to the active area.

b) The two sides of the electrode glass are clamped using a binder clip so that they are fully attached.

c) The two sides of the electrode offset are connected by a jumper cable and clamped using a crocodile claw.

d) The structure of the Dye Sensitized Solar Cell (DSSC) which has been prepared, is already in the form of a structure with sandwich 0.1 $\mathrm{ml}$ of electrolyte drop through the offset gap.

7) DSSC Circuit Testing

a) Halogen lamps were installed using a stative upright position in accordance with the positioning position of the DSSC.

b) DSSC components are connected to the project board that is connected to the ammeters, voltmeter and potentiometer circuits.

c) Set the DSSC circuit that has been connected to the current value and the stable voltage.

d) Potentiometer is rotated every 15 seconds from the minimum point to the maximum point.

e) Data from the measurement of current and voltage can be seen on the multimeter.

f) Record the measurement results. 


\section{MATH AND EQUATIONS}

The parameters observed include power and efficiency of Dye Sensitized Solar Cell (DSSC).

\section{Power Measurement}

The intensity of light affects the absorption of Dye Sensitized Solar Cell (DSSC). Measurement of absorption Dye Sensitized Solar Cell (DSSC) can be done using equation (1), [9].

$$
\mathrm{P}_{\text {input }}=\mathrm{J} \text {. A }
$$

Description:

$\mathrm{P}_{\text {input }} \quad$ : Power absorbed from light sources $(\mathrm{mW})$

J : Light intensity $\left(\mathrm{mW} / \mathrm{cm}^{2}\right)$

A : Active surface area $\left(\mathrm{cm}^{2}\right)$

Calculating the amount of power produced by solar cells can use equation (2), [9].

$$
\mathrm{P}_{\text {output }}=\mathrm{V}_{\mathrm{oc}} \cdot \mathrm{I}_{\mathrm{sc} .} \mathrm{FF}
$$

(2)

Description:

$\begin{array}{ll}\mathrm{P}_{\text {output }} & \text { : Power generated }(\mathrm{mW}) \\ \mathrm{V}_{\mathrm{oc}} & \text { : Open circuit voltage }(\mathrm{mV}) \\ \mathrm{I}_{\mathrm{sc}} & \text { : Short circuit current }(\mathrm{mA}) \\ \mathrm{FF} & \text { : Fill Factor }\end{array}$

2. Efficiency DSSC

The efficiency of solar cells shows a lot of photon energy that can be converted directly into electrical energy. Efficiency values are obtained by comparing the power produced by Dye Sensitized Solar Cell (DSSC) $\left(\mathrm{P}_{\text {output }}\right)$ with the power absorbed by the active surface area $\left(\mathrm{P}_{\text {input }}\right)$. The width of the absorption area will affect the resulting efficiency. Efficiency values are obtained by calculations using equation (3), [2].

$$
\eta=\left(\frac{P_{\text {out }}}{P_{\text {in }}}\right)\left(\frac{P_{\text {out }}}{P_{\text {in }}}\right) \times 100 \% \ldots \ldots . .
$$

\footnotetext{
Description:

$P_{\text {in }} \quad:$ Power absorbed $(\mathrm{mW})$

$\mathrm{P}_{\text {out }} \quad$ : Power generated $(\mathrm{mW})$
}

\section{FIGURES AND TABLES}

\subsection{DSSC Power}

Power output of a DSSC is closely related to the value of current and voltage generated at the time of measurement. If the value of the current and voltage generated at the measurement level is high, the power generated is also high and the opposite is true. The less the result of the conversion of energy into electricity, the power obtained is also small. In the energy conversion process by DSSC, there are a number of calculated power including power input $\left(\mathrm{P}_{\text {in }}\right)$, power output $\left(\mathrm{P}_{\text {out }}\right)$ and maximum power $\left(\mathrm{P}_{\max }\right)$, maximum power and output power are the same value. The Power output produced by each DSSC is presented in Figure 4.1 .

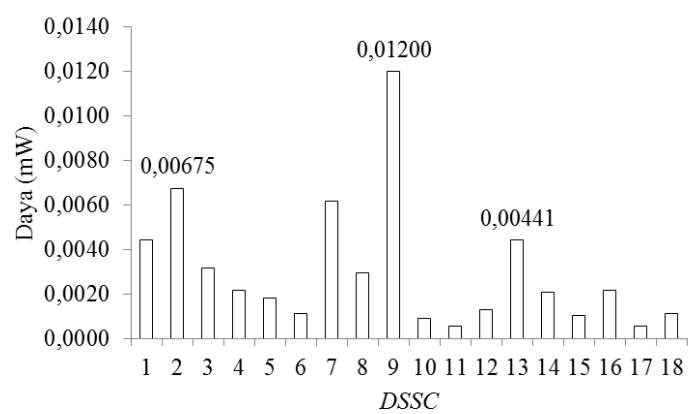

Figure 4.1. DSSC power output
Description:

DSSC 1: $10 \mathrm{~cm}, 0$ seconds soaking DSSC 2: $10 \mathrm{~cm}, 5$ seconds soaking DSSC 3: $10 \mathrm{~cm}, 10$ seconds soaking DSSC 4: $10 \mathrm{~cm}, 15$ seconds soaking DSSC 5: $10 \mathrm{~cm}, 20$ seconds soaking DSSC 6: $10 \mathrm{~cm}, 25$ seconds soking DSSC $7: 20 \mathrm{~cm}, 0$ seconds soaking DSSC 7: $20 \mathrm{~cm}, 0$ seconds soaking DSSC 8: $20 \mathrm{~cm}, 5$ seconds soaking
DSSC 9: $20 \mathrm{~cm}, 10$ seconds soaking

DSSC 10: $20 \mathrm{~cm}, 15$ seconds soaking DSSC 11: $20 \mathrm{~cm}, 20$ seconds soaking DSSC 12: $20 \mathrm{~cm}, 25$ seconds soaking DSSC 13: $30 \mathrm{~cm}, 0$ seconds soaking DSSC $14: 30 \mathrm{~cm}, 5$ seconds soaking DSSC 15: $30 \mathrm{~cm}, 10$ seconds DSSC 16: $30 \mathrm{~cm}, 15$ seconds soaking DSSC 16: $30 \mathrm{~cm}, 15$ seconds soaking DSSC 17: $30 \mathrm{~cm}, 20$ seconds soaking DSSC 18: $30 \mathrm{~cm}, 25$ seconds soaking
The value of a current and voltage affects the amount of power DSSC output. The light source used in this study is a 50 Watt halogen lamp. Halogen lamps are lamps that have the nature of light that almost resembles sunlight, besides that halogen lamps emit stable polychromatic light with a fairly wide wavelength range [5].

Figure 4.1. shows DSSC power output with a distance of $20 \mathrm{~cm}$ with a light intensity of $303.23 \mathrm{~mW}^{2}$ and a soaking time of 10 seconds has a higher value than the others. The output highest power is found in DSSC 2, DSSC 9 and DSSC 13 with each distance of the light source, while the resulting value of 0.00675 $\mathrm{mW}, 0.012 \mathrm{~mW}$, and $0.00441 \mathrm{~mW}$ respectively. DSSC 9 is DSSC which has the highest overall value, it is due to the effect of soaking time so that absorption occurs dye optimal and also because the light intensity received by DSSC 9 is greater. The Power output lowest obtained from DSSC 11 and 17 that is equal to $0,00056 \mathrm{~mW}$. That is because the amount of light that is able to be received by DSSC, the intensity of light received is large but due to the absorption of dye by the surface of $\mathrm{TiO} 2$ is not optimal, causing the ability DSSC to absorb photon energy is reduced. The amount of power is also influenced by the value of Isc, Voc, and FF. At a distance of $30 \mathrm{~cm}$ with a light intensity value of 299.62 $\mathrm{mW}^{2}$ the power output produced is very small when compared to other light intensities it is influenced by the amount of light received by DSSC. If the distance of the 
DSSC from the light source is far, the photon energy absorbed by DSSC will be less, so that the conversion of light energy into electricity will also be smaller. The treatment of different light source distances will provide different light intensities so that it will affect the power output produced by DSSC [12].

\subsection{DSSC Efficiency}

Efficiency is the most commonly used parameter to compare the quality of the overall performance of solar cells. Efficiency is defined as the ratio of the output energy from solar cells for energy inputs is absorbed from the sun. Efficiency can be used as a measure on DSSC to convert sunlight energy into electrical energy. The efficiency of a DSSC can be calculated by dividing thepower output $\left(\mathrm{P}_{\text {out }}\right)$ with thepower input $\left(\mathrm{P}_{\text {in }}\right)$, in this study the efficiency is expressed in percent units. The efficiency value is influenced bypower DSSC output. The closer thepower outputis to thepower input, the more energy that is successfully converted to electricity and the greater the efficiency value. The efficiency of DSSC in this study has different values and is presented in Figure 4.2

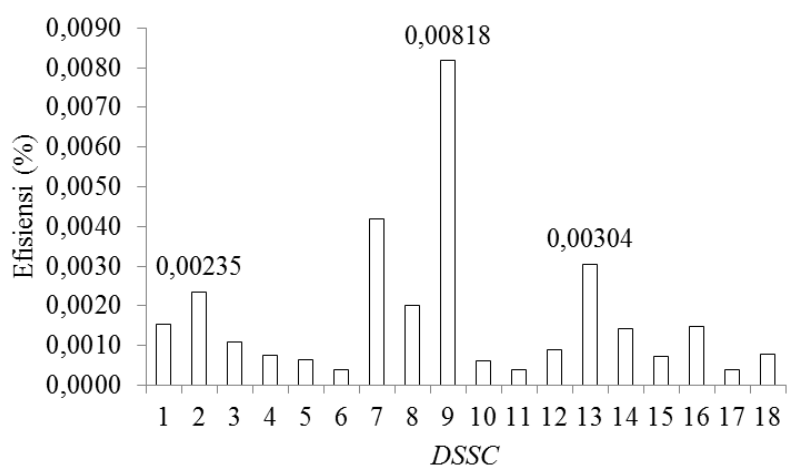

Figure 4.2. DSSC Efficiency

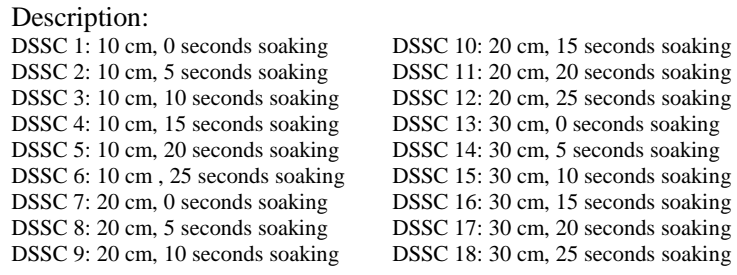

DSSC 10: $20 \mathrm{~cm}, 15$ seconds soaking DSSC 11: $20 \mathrm{~cm}, 20$ seconds soaking DSSC 12: $20 \mathrm{~cm}, 25$ seconds soaking DSSC 13: $30 \mathrm{~cm}, 0$ seconds soaking DSSC 14: $30 \mathrm{~cm}, 5$ seconds soaking DSSC 15: $30 \mathrm{~cm}, 10$ seconds soaking DSSC 16: $30 \mathrm{~cm}, 15$ secolds soling DSSC 17: $30 \mathrm{~cm}, 20$ seconds DSSC 17: $30 \mathrm{~cm}, 20$ seconds soaking DSSC 18: $30 \mathrm{~cm}, 25$ seconds soaking

Figure 4.2. shows that the value of DSSC efficiency at a distance of $10 \mathrm{~cm}$ from a light source is in the range of $0,00039 \%$ to $0.00235 \%$, at a distance of $20 \mathrm{~cm} \mathrm{DSSC}$ has an efficiency ranging from $0,00038 \%$ to $0.00818 \%$, at a distance of $30 \mathrm{~cm}$ DSSC efficiency ranges from $0,00039 \%$ to $0.00304 \%$. The highest efficiency value was obtained from DSSC with a soaking time of 10 seconds.

\section{CONCLUSION}

The conclusions obtained from this study are as follows:

1. The variation of the immersion time of the Titanium Dioxide $\left(\mathrm{TiO}_{2}\right)$ in dye yellow sweet potato extractand light intensity affects the performance produced by the Dye Sensitized Solar Cell (DSSC).

2. DSSC 9 is DSSC which has thepower value output highest overallthat is valued at $0.012 \mathrm{~mW}$ and the lowest is obtained from DSSC 11 and 17 which is equal to $0,00056 \mathrm{~mW}$.

3. The value ofefficiency DSSC at a distance of 10 $\mathrm{cm}$ from a light source is in the range of $0,00039 \%$ to $0.00235 \%$, at a distance of $20 \mathrm{~cm}$ DSSC has an efficiency ranging from $0,00038 \%$ to $0.00818 \%$, at a distance of $30 \mathrm{~cm}$ theefficiency DSSC is around between $0,00039 \%$ to $0.00304 \%$. The highest efficiency value was obtained from DSSC with a soaking time of 10 seconds.

\section{ACKNOWLEDGMENTS}

The author thanks Nurul Izzah Aulia, Abu Hasan and RD Kusmanto for their contribution to this study. Thank you also to Politeknik Negeri Sriwijaya for the facilities in this study.

\section{REFERENCES}

[1] Andaria, S., 2018. Dye Sensitized Solar Cell Dengan Ekstrak Bunga Kencana Ungu (Ruellia Tuberosa L.) Sebagai Pemeka Cahaya. Skripsi. Universitas Sriwijaya.

[2] Ardianto, R., Nugroho, W.A., dan Sutan, S.M., 2015. Uji Kinerja Dye Sensitized Solar Cell (DSSC) Menggunakan Lapisan Capacitive Touch Screen Sebagai Substrat Dan Ekstrak Klorofil Nannocholopsis Sp. Sebagai Dye Sensitizer Dengan Variasi Ketebalan Pasta $\mathrm{TiO}_{2}$. Jurnal Keteknikan Pertanian Tropis dan Biosistem, 3(3), 325-337.

[3] Damayanti, R., Hardeli, dan Hari, S., 2014. Preparasi Dye Sensitized Solar Cell (DSSC) Menggunakan Ekstrak Antosianin Ubi Jalar Ungu (Ipomoea Batatas L.). Jurnal Sanistek, 6(2), 148-157.

[4] Faruqi, A.F., Kusumanto, Rd., dan Hasan, A., 2019. Optimization of Monocrystalline

Solar Panels Using Reflector Scanning Technology. Journal of Physics: Conf. Series 1167(2019)012024, page: 1 .

[5] Nasukhah, A.T., dan Prajitno, G., 2012. Fabrikasi dan Karaterisasi Dye Sensitized Solar Cell (DSSC) Dengan Menggunakan Ekstraksi Daging Buah Naga Merah (Hylocereus Polyrhizus L.) Sebagai Dye Sensitizer. Jurnal Sains dan Seni Pomits, 1(1), 1-6. 
[6] Negara, H.K., Kusumanto, Rd., dan Hasan, A., 2019. Effects of Direct Window Film Installation on Photovoltaic Solar Panel. Journal of Physics: Conf. Series 1167(2019)012029, page: 2.

[7] Nugrahawati, Dewi, 2012. Fabrikasi Dye Sensitized Solar Cell (DSSC) Menggunakan Mawar Merah (Rosa Damascena Mill) Sebagai Pewarna Alami Berbasis Antosianin. Skripsi. Universitas Sebelas Maret.

[8] Prasetyowati, R., 2012. Sel Surya Berbasis Titanian Sebagai Sumber Energi Listrik Alternatif. Skripsi. Universitas Negeri Yogyakarta.

[9] Pratiwi, D.D., 2016. Variasi Zat Komposit Zat Pewarna Terhadap Kinerja Dye Sensitized Solar Cell (DSSC). Skripsi. Universitas Sebelas Maret.

[10] Rahman, M.A., Sholeh, H.P., dan Eka Maulana, 2015. Pengaruh Variasi Ketebalan Titanium
Dioksida $\left(\mathrm{TiO}_{2}\right)$ Terhadap Daya Keluaran Dye Sensitized Solar Cell (DSSC). Makalah Penelitian. Universitas Brawijaya.

[11] Susanto, B.A., S. Khoirun, N., Nita, R., dan Agus, Y., 2014. Analisis Spektrum Absorbansi Pigmen Flavonoid Dari Daun Tanaman Andong (Cordyline Fruticosa L.) Sebagai Dye Solar Sel. Jurnal Fisika. 4(2), 93-95.

[12] Wulandari, L., 2018. Dye Sensitized Solar Cell (DSSC) dengan Ekstrak Kangkung Air (Ipomoea Aquatic F.) sebagai Pemeka Cahaya. Skripsi. Universitas 